Scientific Electronic Archives

Issue ID: Sci. Elec. Arch. Vol. 14 (9)

September 2021

DOI: http://dx.doi.org/10.36560/14920211452

Article link: https://sea.ufr.edu.br/SEA/article/view/1452

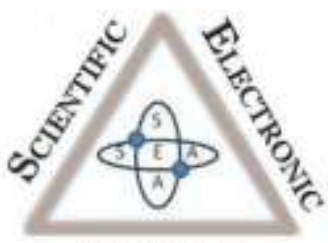

ArChives

ISSN 2316-9281

\title{
Analysis of sea trial data of the ship's main motor using the overview engine control unit
}

Corresponding author

Kaminton Tambunan

Department of Fishing Technology, Fisheries Machine Faculty, Kupang Marine and Fisheries Polytechnic, Kupang East Southeast Nusa, Indonesia kamintontambunann@gmail.com

Febi Luthfiani

Department of Fishing Technology, Fisheries Machine Faculty, Kupang Marine and Fisheries Polytechnic, Kupang East Southeast Nusa, Indonesia

I Made Aditya Nugraha

Department of Fishing Technology, Fisheries Machine Faculty, Kupang Marine and Fisheries Polytechnic, Kupang East Southeast Nusa, Indonesia

\begin{abstract}
This study was conducted to obtain the results of mapping and analysis of sea trial data after maintenance of the motor lubrication and cooling system using the Engine Control Unit (ECU) so that recommendations for maintenance activities for damage control have been completed. The results of data analysis indicate that the pressure and temperature in the system return to normal in the allowable parameters tend to be the same or there is no change if repeated at the same rotation, the pressure rises and falls according to the engine speed. This data is an indicator that both system data has been successfully returned after treatment. Engineers should always write down the data in the engine journal so that if the ECU records data that is not in accordance with sea trial data, maintenance is immediately carried out to avoid further damage.
\end{abstract}

Keywords: Sea trial; Source of disturbance; Performance; Lubrication system; Cooling system; Overview engine control unit.

\section{Introduction}

Main propulsion motor (MPU) is the power needed to move the ship. Motor work data is very important to know and record in a machine journal diary (Wiranto \& Koichi, 1993). Overview engine control unit is a tool for reading, recording and notifying motor condition data, this is very necessary to determine whether the machine is properly operated (Yudhiarma, 2006). Of course, normal engine condition data is a priority source to ensure that the motorbike is always in seaworthiness. The engine control unit is very important for early detection of normal motor work and any source of engine work system disturbances. Ship engine engineers must have vocational education, competency in analyzing engine disturbance sources to make it easier to use the benefits of the ECU. Most of the existing surveillance vessels of course really need seaworthiness at all times. Supervision ships are the front line to protect the sovereignty of natural resources from fish thieves or those who violate the fishing territory (Harrington, 1971). The ship engine ECU has the ability to record and read the work of the engine support systems, and provide feedback about the system's work presence (Karyanto, 2000). Therefore, it is necessary to study and understand machine support systems through applications, where the system work results will be recorded, read and the results recorded in the machine's daily journal. The journal is a control record of the machine's presence during operation to ensure the system works normally. Human resource development, competence and interaction with a machine diary are very important in order to carry out maintenance and repair of machines to achieve the four zero point's industrial revolution (4.0) (Haryadi, 2012). ECU technology for engine work systems is currently installed on marine and fisheries supervisory vessels, for monitoring illegal fishing. In the analysis of the motor work of 
the ship propulsion, the ECU is monitored and the results are recorded in the engine journal book with the main objective to evaluate the performance of the ship propulsion engine support system (Suparwo, 2013). Because this is the pioneer of the machine work system application technology program, the results of this study are very important for future programs to improve technology and human resources for Indonesian fisheries supervisory vessels, especially the industrial revolution 4.0 .

\section{Material and Method}

This research is descriptive quantitative research by obtaining the data from engine control unit. Quantitative research is a research study that focuses on quantity. The purpose of quantitative descriptive has purposes to decide the relation among the variables of population (Sugiyono, 2016). The study of sea trial data analysis of the main motor of the ship was carried out on the Orca 02 Supervisory Ship of the Directorate General of
Surveillance and Control of Marine and Fishery Resources, this government institution is under the management of the Ministry of Marine Affairs and Fisheries.

\section{Result}

Motor Boat Orca 02

It officially formed on 23 November 2000 based on the Presidential Decree Number 165 of 2000, Directorate General of PSDKP is Directorate General that responsible for overseeing marine and fisheries resources (Kusumadewi \& Hartati, 2006). In conducting supervision, the Directorate General of PSDKP coordinates with the Indonesian Navy, Indonesian Maritime Security Agency and The Air and Water Police. The Directorate General of Surveillance and Control of Marine and Fishery Resources has a slogan namely Nusantara Lestari Jaya. The head office is located at Mina Bahari 4 Building, 11th Floor, Jalan Medan Merdeka Timur Number 16, Central Jakarta. Tel (021) 3519070.

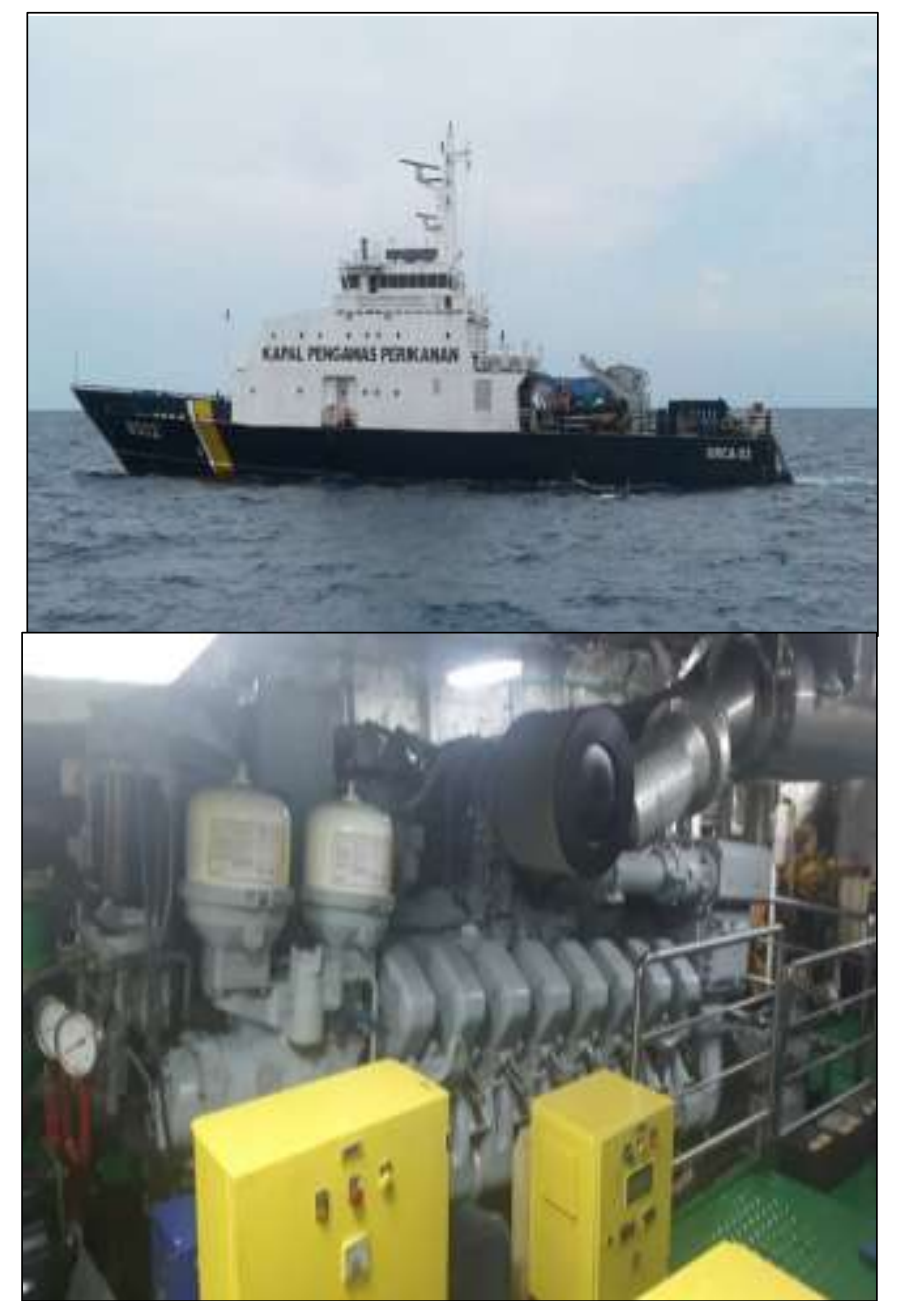

Fig. 1. The fishing control vessel Orca 02 and the ship's main propulsion.

\section{Application and Operation of Machines}

The work support systems for the ship's main propulsion engines are sampled in the engine control room (Engine Control Unit); engine speed (rpm), ship speed (miles/hour). Lubricating oil pressure (bar), temperature lubricants $\left({ }^{\circ} \mathrm{C}\right)$, the cooling water temperature $\left({ }^{\circ} \mathrm{C}\right)$, the exhaust gas temperature $\left({ }^{\circ} \mathrm{C}\right)$, where the system is grouped on 
the observation of pressure and temperature is then listed on the diary of the work machine (Figure 2).

Engine speed (rpm) experiments were carried out at different rotations and were set at three variations of engine speed; low speed 600-900rpm, medium speed; 1000-1200rpm, and a high speed of 1400-1600rpm, and each rotation is maintained at a constant position, the application will read and record the system operation at each rotation and results (Suharto, 2011). During operation, the pressure (pressure lube oil, pressure fuel, pressure charge air and crank case (figure 3) on the cover view of the ECU, engine control unit, engine speed, injection quality, pressure lube oil, temperature cooler, temperature cooling water and temperature exhaust combustion (figure 4).
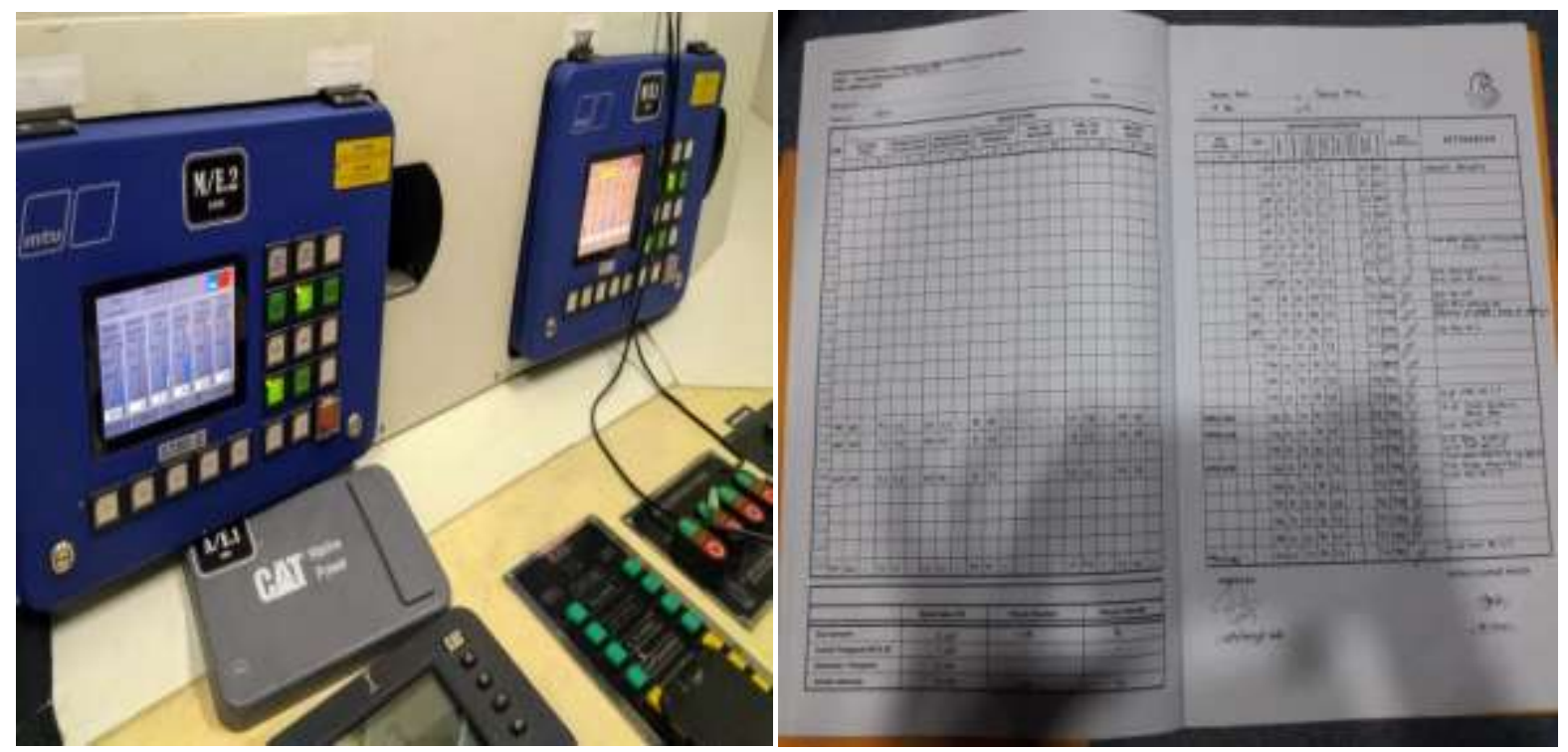

Figure. 2. Engine control unit ECU and journal diary

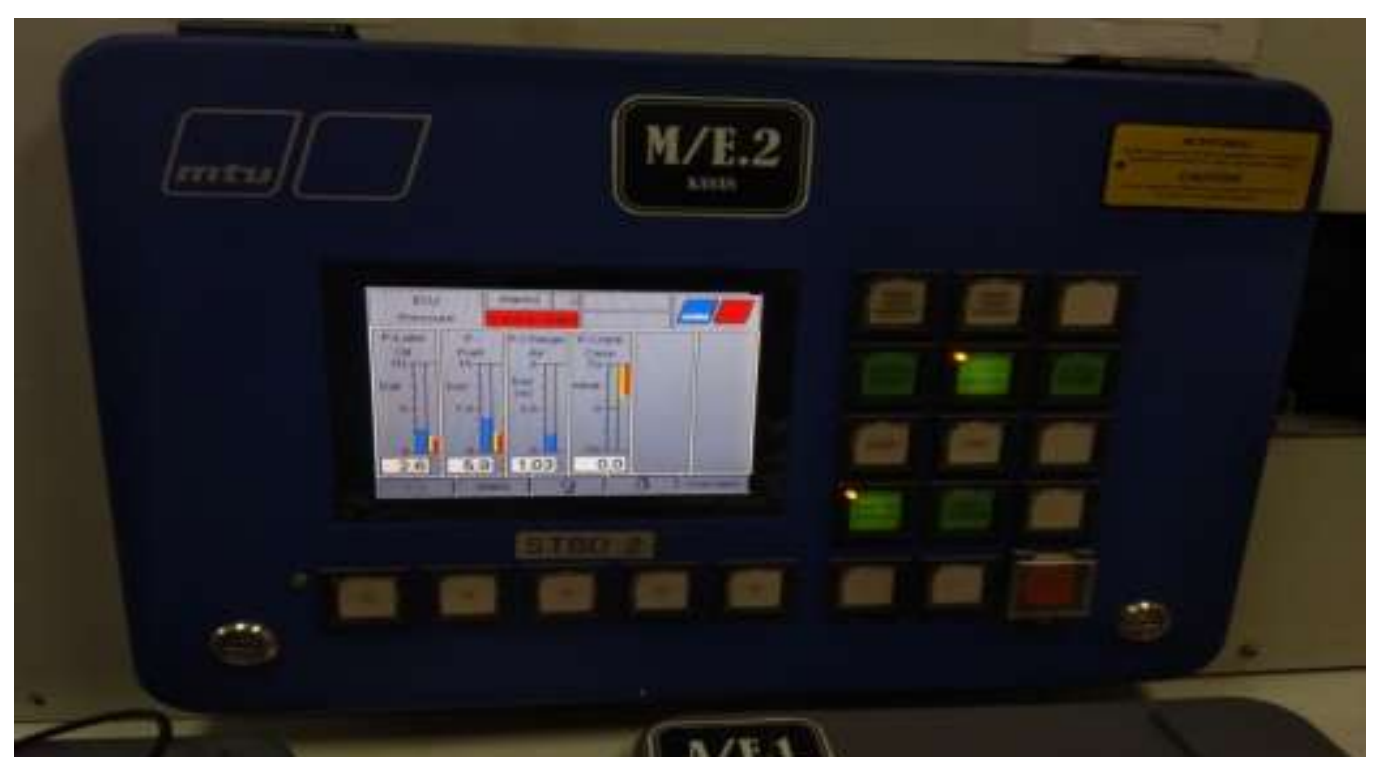

Figure. 3. Lubricating oil pressure 


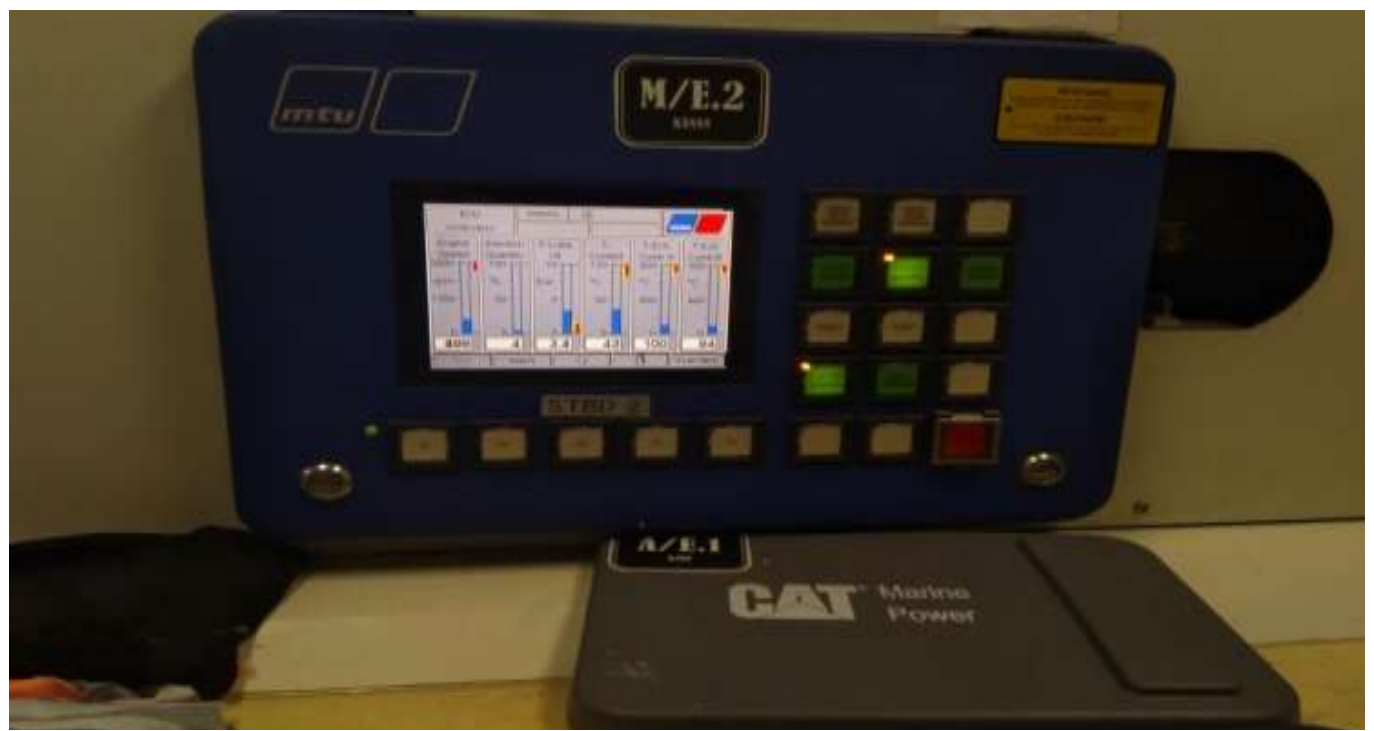

Figure. 4. Temperature

\section{Overview engine control}

All data tested is illustrated using a graphical chart table. and presented in brief descriptions Analysis of the detection of sources of disturbance to treatment, pressure and temperature was carried out by FMEA (Failure mode and effect analysis using Lenovo Yoga laptop software. Overview engine control unit monitors, reads and records work data of engine support systems (table 1) engine speed follows engine speed (rpm), if you see the application recordings at 600 rpm, 700 rpm, 900rpm each, 1000rpm; 1200rpm; 1400rpm and $1600 \mathrm{rpm}$, showing the difference in pressure and temperature. If the speed of the ship is protected at the same rotation, it means that being repeated at the same rotation will have the same pressure record results, likewise the temperature tends to follow the pressure and returns to the original temperature at the same speed (Figure 5).

The above curve also reads and records where abouts the work of the system in the crank room (charter), tends to follow the rise and fall of the engine speed (table 2).

a. $\quad$ Lubricating oil Pressure Reducer.

Ship speed at 600rpm; 700rpm; 900rpm; 1000rpm; 1200rpm; 1400rpm and 1600rpm engine speed, reading applications, record the work of the lubrication system where the recording results are obtained by the lubricating oil pressure (3.7bar; 3.8bar; 3.9bar; 4.0bar; 4.2bar; 4.3bar and 5.8bar).

b.

Decreasing temperature of

lubricating oil

Ship speed at 600rpm; 700rpm; 900rpm; 1000rpm; $1200 \mathrm{rpm} ; 1400 \mathrm{rpm}$ and $1600 \mathrm{rpm}$ engine speed, the application reads the work of the lubrication system in which the recorded temperature is $\left(52^{\circ} \mathrm{C} ; 60^{\circ} \mathrm{C} ; 77^{\circ} \mathrm{C} ; 84^{\circ} \mathrm{C} ; 93^{\circ} \mathrm{C} ; 98^{\circ} \mathrm{C}\right.$ and $105^{\circ} \mathrm{C}$ ).

c. Cooling water temperature

reduction

Ship speed at 600rpm engine speed; 700rpm; 900rpm; 1000rpm; 1200rpm; $1400 \mathrm{rpm}$ and 1600 rpm, applications for reading the work of the cooling system where the temperature records are obtained $\left(55^{\circ} \mathrm{C} ; 60^{\circ} \mathrm{C} ; 63^{\circ} \mathrm{C} ; 65^{\circ} \mathrm{C} ; 68^{\circ} \mathrm{C} ; 72^{\circ} \mathrm{C}\right.$ and $\left.74^{\circ} \mathrm{C}\right)$ while for the exhaust gas temperature $A\left(150^{\circ} \mathrm{C}\right.$; $300^{\circ} \mathrm{C} ; 400^{\circ} \mathrm{C}$ ) (table 1)The engine control unit also records lubricant pressure $(3.2 ; 3.4 ; 3.7)$ fuel pressure $(6.1 ; 6.3 ; 6.7)$, air pressure $(1.06)$ and the pressure in the crank tube (0.0) (table 2), pressure and temperature readings or records. The ECU is recorded in the engine's daily journal, the record is used as a standard reference that the engine is working normally and stably. basic guidelines or standards as a reference in measuring a change in an activity or event.

The pressure and temperature in the engine support systems in the engine control room are presented in Figure (6) the increase in pressure and temperature is generally higher at high rotation variations. The difference arises due to differences in engine speed, but this difference shows that the system functions and works according to engine speed. The results of recording pressure and temperature on the ECU are indicators of system work.

Over view of the engine control unit (table 1), showing the pressure / temperature of the lubrication and the temperature of the cooling water are normal indicators or indicators used by the Orca 02 motor boat engineer as an indication that the engine performance is in sea lake conditions. Based on engine speed, there is no change in pressure at the return of the engine speed in the same rotation. The ECU records both the pressure and temperature indicators showing an increase in the speed of the medium-speed and high-speed engine, and back down at low speed, when there is a repetition at the same engine speed or returned at the same speed, each pressure and temperature returns to the position the same value (figure 5). The results showed that the ECU in the engine control unit recorded, recorded the system's work and the results of the sea trial record showed that the lubrication system and the cooling system worked in 
accordance with the standard parameters set by the manufacturer. From the engine speed as long as the system is working properly (Petrovsky, 1968), the pressure and temperature may change given the engine that works continuously, engine speed changes and the speed of the ship is affected by wind and wave resistance, this will affect the pressure. and temperature at an abnormal position occurrence any abnormal in the ship's main propulsion engine system will have a very wide impact on all materials or engine parts on which the engine unit is formed (Handoyo, 2007).

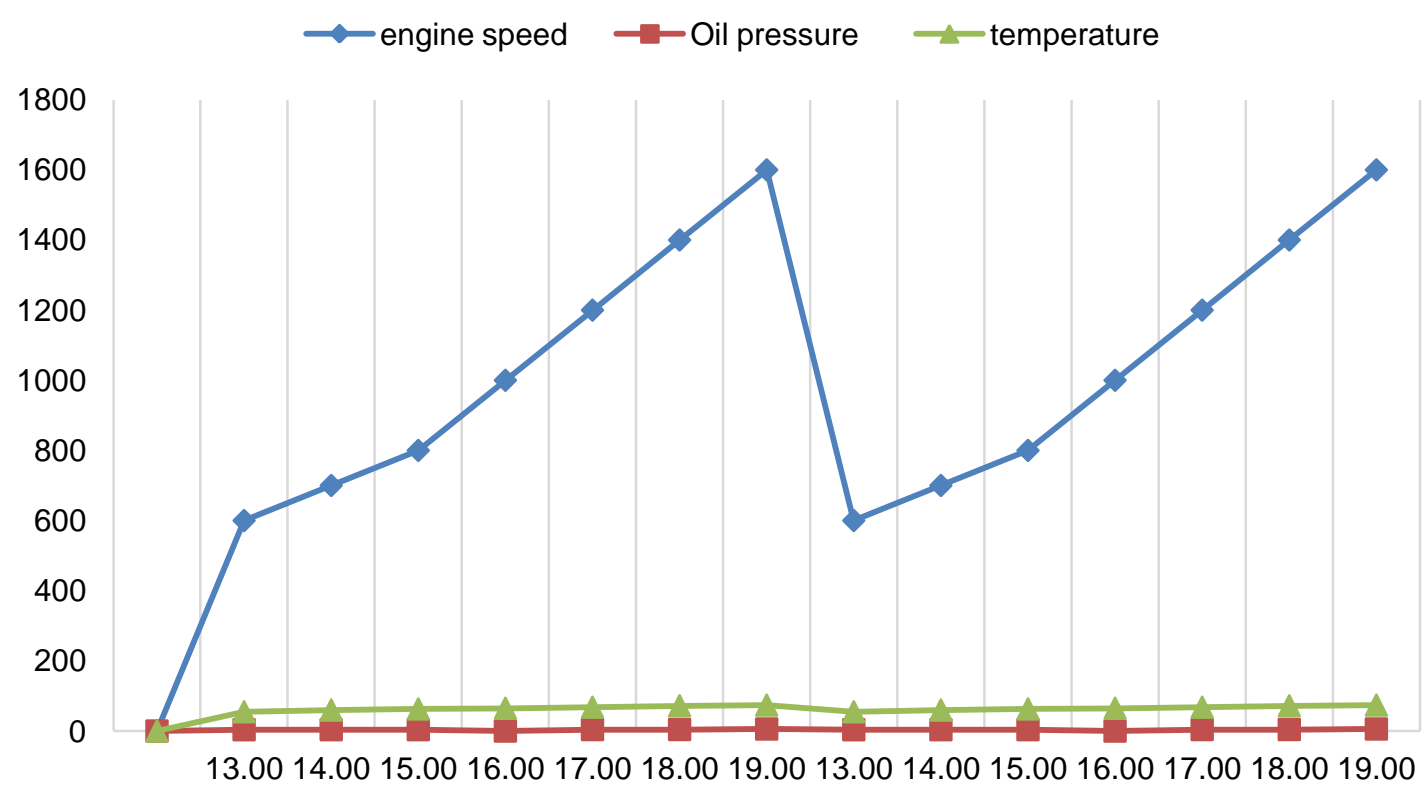

Figure. 5. The Relation Between Engine Speed To Pressure And Temperature

Table 1. Overview Engine Control Unit

\begin{tabular}{|c|c|c|c|c|c|c|}
\hline engine speed & $\begin{array}{l}\text { injection } \\
\text { quality }\end{array}$ & $\begin{array}{c}\text { P- lube } \\
\text { oil }\end{array}$ & $\begin{array}{c}\text { T- } \\
\text { cooler }\end{array}$ & $\begin{array}{c}\text { T- } \\
\text { cooling water }\end{array}$ & $\begin{array}{c}\text { T- exhaust } \\
\text { combustion A }\end{array}$ & $\begin{array}{c}\text { T- exhaust } \\
\text { combustion } \mathrm{B}\end{array}$ \\
\hline 600 & 5.0 & 3,7 & 52 & 55 & 100 & 110 \\
\hline 700 & 6.5 & 3,8 & 60 & 60 & 110 & 110 \\
\hline 900 & 8.0 & 3,9 & 77 & 63 & 150 & 165 \\
\hline 1000 & 11 & 4.0 & 84 & 65 & 190 & 210 \\
\hline 1200 & 12.5 & 4,2 & 93 & 68 & 300 & 335 \\
\hline 1400 & 14 & 4,3 & 98 & 72 & 350 & 435 \\
\hline 1600 & 16 & 5,8 & 105 & 74 & 400 & 550 \\
\hline
\end{tabular}

Source : own study

Table 2. Pressure engine control unit

\begin{tabular}{cccc}
$\begin{array}{c}\text { P- lube } \\
\text { oil }\end{array}$ & $\begin{array}{c}\text { P- } \\
\text { fuel }\end{array}$ & $\begin{array}{c}\text { P-charge } \\
\text { air }\end{array}$ & $\begin{array}{c}\text { P-crank } \\
\text { case }\end{array}$ \\
\hline 2.9 & 5.1 & 1.06 & 0.0 \\
3.0 & 5.2 & 1.06 & 0.0 \\
3.2 & 6.1 & 1.06 & 0.0 \\
3.25 & 6.15 & 1.06 & 0.0 \\
3.4 & 6.3 & 1.06 & 0.0 \\
3.6 & 6.4 & 1.06 & 0.0 \\
3.7 & 6.7 & 1.06 & 0.0 \\
\hline
\end{tabular}

Source: own study 


\section{pressure and temperature}

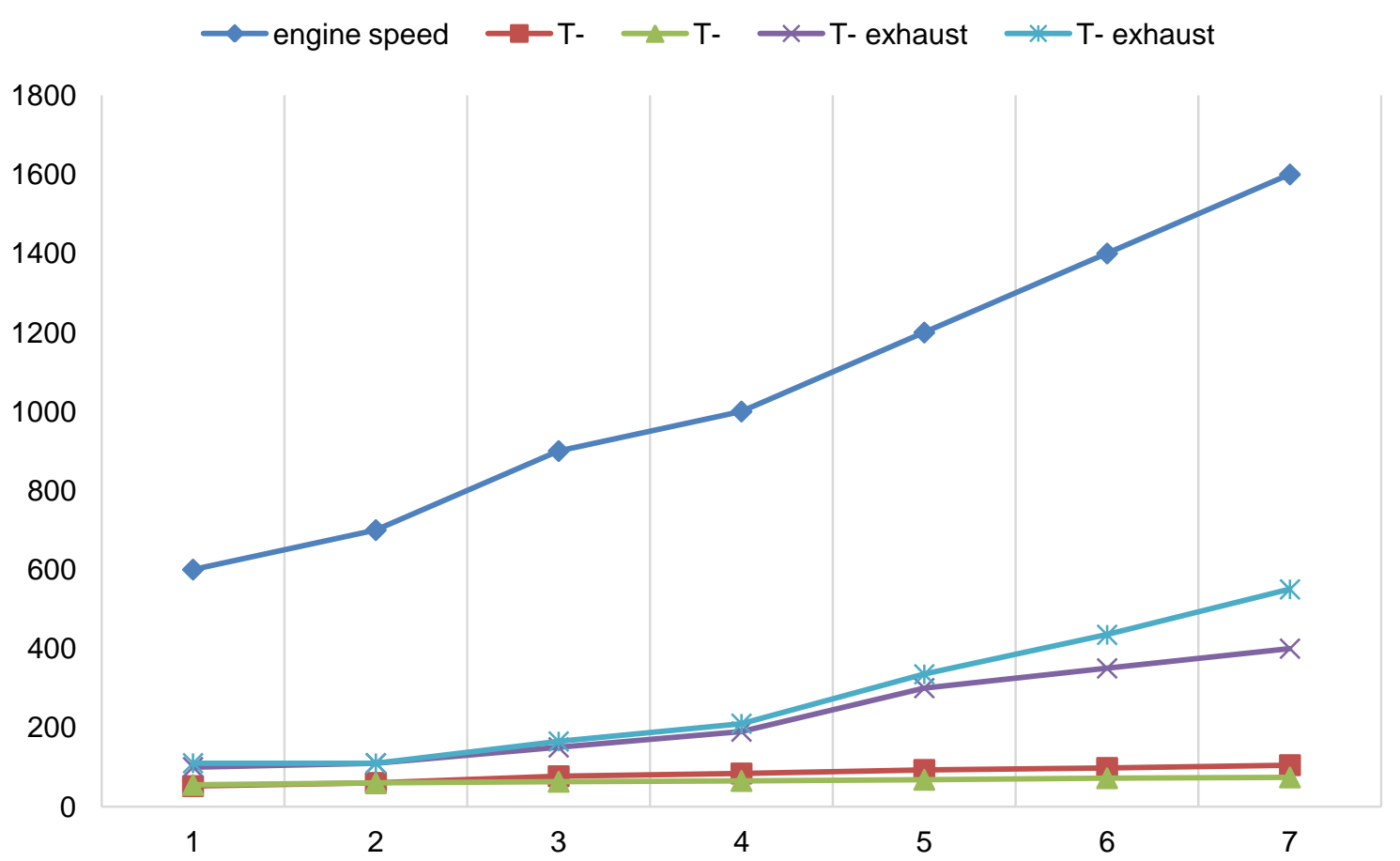

Figure. 6. The relationship between speed of vessel against pressure and temperature

This will be a message that is concerned about the safety of the crew, the operation of the ship, and if the ECU records or reads abnormal pressure and temperature (Figure 7), repairs are immediately carried out to avoid greater / heavier damage. Normal pressure and temperature capacity will produce engine performance, restore engine work to the better, so it is imperative to maintain engine support systems, control and record application readings and write them in a machine journal book. If there is a change in pressure that drops or rises from normal limits, machine maintenance must be performed. The results also show that the ECU reads and records all system work events, related to system abnormalities (Figure 8), which may be caused by system components that have run out of life so that spare parts are needed. Even though the machine's work support systems work normally according to the engine speed, when there is a system work abnormality this becomes the basis for carrying out maintenance. The pressure generated by the lubricating oil pump. The ability to pump is directly proportional to the engine speed, if the engine is running slowly, the pump also pumps slowly, whereas when the engine is rotating fast, the lubricating oil pump also pumps quickly. If the pressure is excessive or reduced, of course, it will have an impact on engine performance. Excessive lubricating oil pressure can cause oil leakage and loss of power in the engine (Handoyo, 2014).

Abnormal temperatures can cause engine damage and even cause an explosion or fire in the engine room (the effect of very high heat (over heat) on lubricating oil (Khan, 2017), lubricating oil will increase in heat and can even boil and form gas that has accumulated with air and forms "vapor mist lubricating oil "(oil mist) in the crank room, theoretically or practically it is impossible to burn spontaneously, there are always ignition trigger factors in general, namely engine components which for some reason cause a heat source. (Handoyo, 2007).

The graph shows system indicators at; temperature, lubricating oil pressure, lubricating pressure and exhaust gas temperature changes, tend to rise and fall at different ship speeds. 


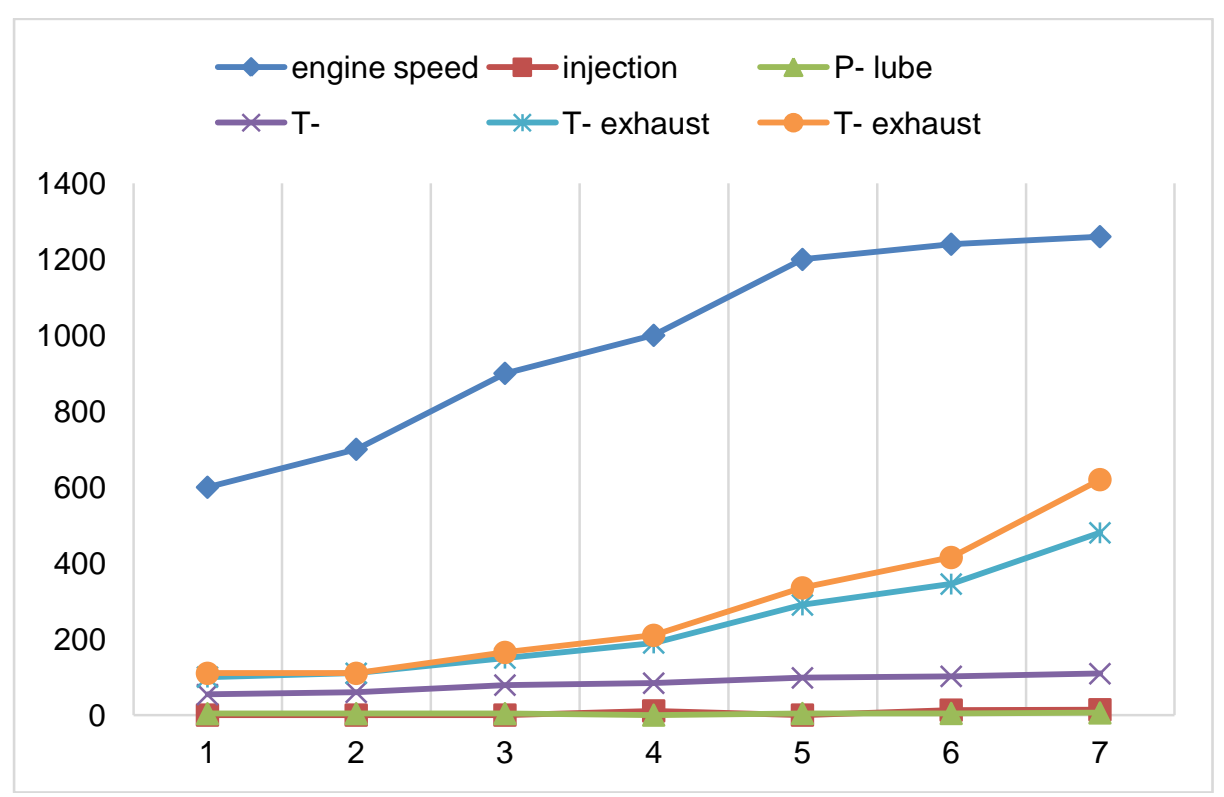

Figure. 7. Graph of velocity against pressure and temperature

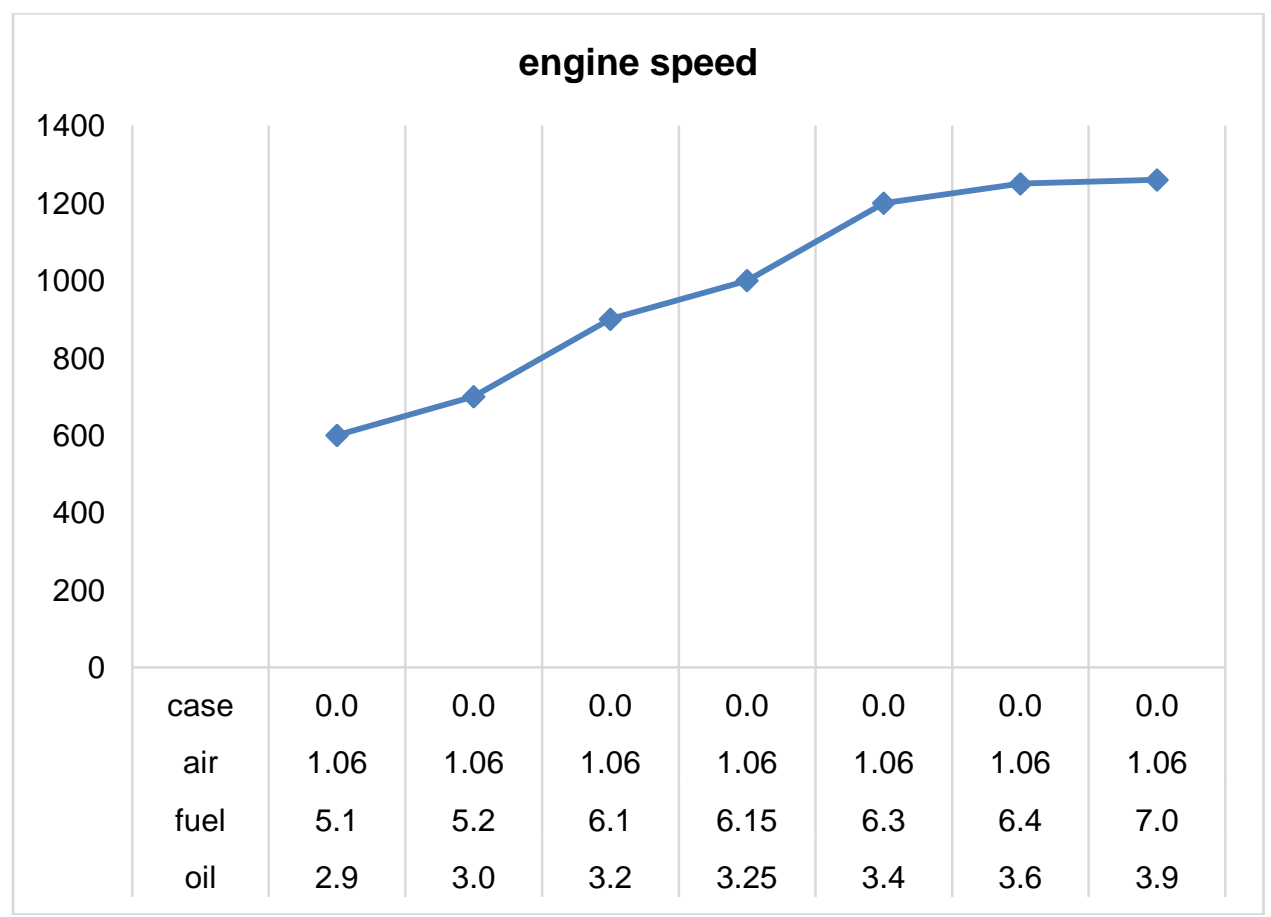

Figure. 8. Graph of velocity against increasing pressure

\section{Conclusion}

This study has succeeded in documenting baseline data for engine support systems and indicators for different engine speeds or engine speeds. The systems work well and are very well controlled following changes in speed, so that it can be proposed as an indicator of the feasibility of the Orca 02 fishing supervisor boat engine to be operated at any time. Changes in normal temperature in the cooling water system are a source of disturbance, this is a concern or the right time to do maintenance. ECU is a technology that is able to detect the presence of a working engine. Analysis of sea trial data on the work of the ship's main propulsion engine is an industrial revolution
4.0 on ship engines, this can develop human resources in the vocational field. Monitoring of machine work systems is carried out at changing speeds. However, continuous systematic monitoring is required to have a deeper understanding of changing systems and dynamics in various ship circumstances.

\section{Acknowledgment}

We are grateful for the close cooperation between the Directorate General of Surveillance and Control of Marine and Fishery Resources and the Polytechnic of Marine and Mussel fisheries. in completing this study. We thank the captain and head of the engine room and all the crew of the 
Orca 02 surveillance ship for their participation and assistance during the field trip.

\section{References}

Handoyo, J. J. (2007). Ship Engine Maintenance and Repair.

Handoyo, J. J. (2014). Diesel Motor Main Drive Engine. Yogyakarta.

Harrington, R. L. (1971). Marine Engineering. The Society of Naval Architect and Marine Engineers. Haryadi, A. M. (2012). Bahan Ajar Pemindahan Panas. Bandung State Polytechnic.

Karyanto, E. (2000). Panduan Reparasi Mesin Diesel. Pedoman Ilmu Jaya.

Khan, S. (2017). Modeling and Temperature Control of Heat Exchanger Process. LAP LAMBERT Academic Publishing.
Kusumadewi, S., \& Hartati, S. (2006). Neuro-Fuzzy Integrasi Sistem Fuzzy dan Jaringan Syaraf. In Graha IImu.

Petrovsky, N. (1968). Marine Internal Combustion Engine.

Sugiyono, P. D. metode penelitian kuantitatif, kualitatif,dan R\&D. , Alfabeta, cv. (2016).

Suharto. (2011). Machine Maintenance Management. Jakarta: PT. Rineka copyright.

Suparwo. (2013). Permesinan Bantu Di Kapal-Kapal Niaga.

Wiranto, A., \& Koichi, T. (1993). High Rotation diesel motor.

Yudhiarma. (2006). Materials Technology 01. Yogyakarta. 